\section{In Vitro Propagation of Ponytail Palm: Producing Multiple-shoot Plants}

\author{
Gilbert L.J. Samyn \\ Centre of Agricultural Research (CLO-Gent), Research Station for Ornamental \\ Plant Growing, B-9090-Melle, Belgium
}

Additional index words. Beaucarnea recurvata, Nolina recurvata, shoot regeneration, root regeneration

Ponytail palm (Beaucarnea recurvata Lem.) is indigenous to desert regions of Texas and Mexico (Everett, 1981). This slow-growing plant is resistant to dry conditions, low relative humidity, and shade, and has remarkable longevity indoors. It is imported into Europe from native regions in the form of whole stems or stem pieces that produce rather expensive plants. Sexual propagation results in a small plant with a swollen stem base and one shoot apex that can be marketed after 1 to 2 years. This paper describes a protocol for in vitro propagation of multiple-shoot, well-acclimatized plants as an alternative to seed propagation.

In vitro culture was started with 1- to $2-\mathrm{mm}$ shoot apexes from young seedlings germinated in peat. After excision, each apex was disinfested for $10 \mathrm{~min}$ in a bleach solution [ $1 \%$ $\mathrm{NaOCl}(\mathrm{w} / \mathrm{v})$ ], rinsed twice for $1 \mathrm{~min}$ in sterile distilled water, and aseptically cultured on a medium containing the following Murashige and Skoog (1962) inorganic salts (mg.liter $\left.{ }^{-1}\right)$ : myo-inositol, 100; nicotinic acid, 1.0; thiamine $\cdot \mathrm{HCl}, 0.5$; pyridoxine $\cdot \mathrm{HCl}, 0.5$; and glycine, 4.0, which was solidified with $6 \mathrm{~g} \mathrm{MC}$ 29 agar/liter (Lab M, Topley House, England). Before autoclaving at $120 \mathrm{C}$ for $20 \mathrm{~min}$, growth regulators were added to the medium and the $\mathrm{pH}$ was adjusted to 5.8. Cultures were maintained at $22 \pm 1 \mathrm{C}$ with a 16 -h photoperiod of 75 $\mu \mathrm{mol} \cdot \mathrm{s}^{-1} \cdot \mathrm{m}^{-2}$ provided by cool-white fluorescent lamps. In the multiplication and rooting experiments, five or six glass vessels, $8 \mathrm{~cm}$ in diameter and containing $75 \mathrm{ml}$ of medium, were planted for each concentration with 10 explants per vessel. Measurements on the effect of $N$-(phenylmethyl)-1H-purine-6-amine (BA) and 1-naphthaleneacetic acid (NAA) on producing multiple-shoot microcuttings per explant and roots per microcutting were subjected to regression analysis.

Surviving and sufficiently developed (1 $\mathrm{cm})$ explants were transferred after 2 months to a multiplication medium (MM) consisting of Quoirin et al. (1978) inorganic salts supplemented with (mg.liter ${ }^{-1}$ myo-inositol, 50; nicotinic acid, 0.5 ; thiamine $\cdot \mathrm{HCl}, 0.25$; pyridoxine $\mathrm{HCl}, 0.25$; glycine, $2.0 ; \mathrm{BA}, 0.5$; gibberellic acid (GA,), 0.1; sucrose, 20,000;

\footnotetext{
Received for publication 28 Sept. 1991. Accepted for publication 19 Oct. 1992. The cost of publishing this paper was defrayed in part by the payment of page charges. Under postal regulations, this paper therefore must be hereby marked advertisement solely to indicate this fact.
}

and MC 29 agar, 6000, at pH 5.8. Explants multiplied well on this medium and formed many shoots on a fast-growing, tuber-like body.

This tuber-like body is an in vitro development of the swollen stem base typical in older plants. To determine the optimal BA concentration for rapid propagation, $\mathrm{MM}$ was supplemented with BA at $0,0.25,0.5$, or 1.0 $\mathrm{mg} \cdot \operatorname{liter}^{-1}(0,1.1,2.2$, or $4.4 \mu \mathrm{M}$ BA). For each concentration, five vessels with 10 explants per vessel were used. Each explant consisted of a piece of the tuber-like body with three clearly developed shoot initials. After3 months, multiplication was determined by counting the number of explants with at least three axillary shoots that were obtained after dividing the tuber-like body and were suited for transfer to rooting medium. No shoot formation resulted without BA in the medium (Fig. 1). Multiplication obtained with BA at 1.0 $\mathrm{mg} \cdot$ liter $^{-1}$ is of practical interest but is limiting, since some of the newly formed leaves remained small and were sometimes distorted. It also becomes difficult to divide the tuber-like body into explants suitable for transfer to rooting medium.

BA completely inhibited root induction and root growth of ponytail palm. However, rooting occurred easily on one-third-strength MS medium without growth regulators, but the number of roots was increased by NAA. The influence of NAA was determined on one-third-strength MS medium supplemented with NAA at $0,0.125,0.250$, or $0.5 \mathrm{mg} \cdot$ liter $^{-1}$ $(0,0.67,1.34$, or $2.68 \mu \mathrm{M}$ NAA). For each concentration, six vessels with 10 explants per vessel from MM were used. Roots were initiated quickly, and they developed well with NAA at 0.125 and $0.250 \mathrm{mg} \cdot \operatorname{liter}^{-1}$ (Fig. 1). A concentration of $0.5 \mathrm{mg} \cdot$ liter $^{-1}$ was too high and caused leaf distortion. Roots formed in the absence of NAA and those induced by NAA developed differently. Without NAA, one or two root initials per explant appeared after 3 to 4 weeks, and each became a fine, very long, branched root. In the presence of NAA, several initials appeared after 2 weeks and remained straight. During the second month, some of the roots started branching. Once transplanted into soil in the greenhouse, there was no difference in adaptation between plants rooted on medium with or without NAA. Although in vitro root initiation occurred in 2 weeks, explants were kept for 6 weeks on rooting medium for further shoot growth and

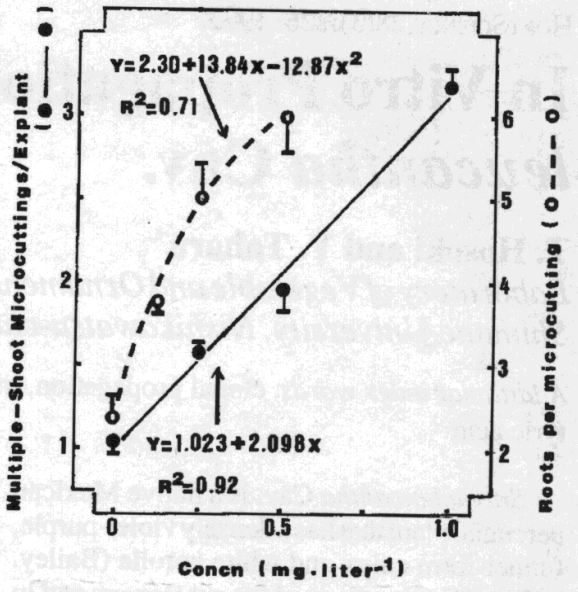

Fig. 1. Influence of BA ( ) on the formation of rootable multiple-shoot microcuttings of ponytail palm and the influence of NAA $(O)$ on rooting the microcuttings. Regression analysis was performed with the means for each concentration of five BA or six NAA vessels with ten explants per vessel. Vertical bars equal $\pm 1 \mathrm{SE}$.

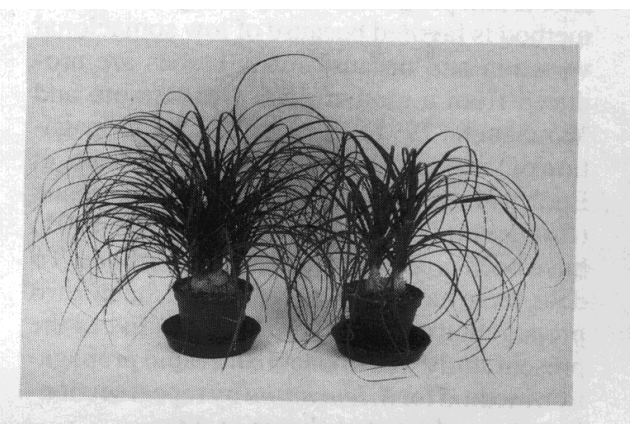

Fig. 2. One-year-old in vitro-propagated, multipleshoot ponytail palms.

suberization at the cut surfaces. Acclimatization occurred under normal greenhouse conditions at 20C. One week after the plants were transplanted into a peat substrate, new root hairs were visible on in vitro-formed roots.

A flexible system can be maintained by harvesting explants for a new multiplication subculture after 2 months, or by harvesting well-developed microcuttings suited for rooting after 3 months. Micropropagation of ponytail palm, in view of producing rooted, multipleshoot plants, is feasible, although a complete cycle takes 5 months. Well-developed plants with at least three shoots meet higher quality standards than seedlings with only one shoot (Fig. 2).

\section{Literature Cited}

Everett, T.H. 1981. The New York botanical garden illustrated encyclopedia of horticulture. vol. 2. Garland Publishing, New York.

Murashige, T. and F. Skoog. 1962. A revised medium for rapid growth and bio-assays with tobacco tissue cultures. Physiol. Plant. 15:473497.

Quoirin, M., M. Lepoivre, and Ph. Boxus. 1977. Un premier bilan de 10 années de recherches sur les cultures de meristèmes et la multiplication 'in vitro' de fruitiers ligneux. Compte rendu de recherches 1976-77. Station de cultures fruitières et maraichères, Gembloux, Belgium. p. 93-117. 